Summer 2007

\title{
The New Public Contracting: Public Versus Private Ordering?
}

Peter Vincent-Jones

University of Leeds

Follow this and additional works at: https://www.repository.law.indiana.edu/ijgls

Part of the Contracts Commons, Government Contracts Commons, and the International Law Commons

\section{Recommended Citation}

Vincent-Jones, Peter (2007) "The New Public Contracting: Public Versus Private Ordering?," Indiana Journal of Global Legal Studies: Vol. 14 : Iss. 2 , Article 4.

Available at: https://www.repository.law.indiana.edu/ijgls/vol14/iss2/4

This Symposium is brought to you for free and open access by the Law School Journals at Digital Repository @ Maurer Law. It has been accepted for inclusion in Indiana Journal of Global Legal Studies by an authorized editor of Digital Repository @ Maurer Law. For more information, please contact rvaughan@indiana.edu.

\section{$\Psi$}

JEROME HALL LAW LIBRARY

INDIANA UNIVERSITY

Maurer School of Law
Bloomington 


\title{
The New Public Contracting: Public Versus Private Ordering?
}

\author{
Peter Vincent-Jones
}

\begin{abstract}
This article explores the hybrid character of contemporary public service organization with specific reference to the emergence in Britain over the last twenty-five years of a novel mode of governance, the "New Public Contracting." The New Public Contracting governs an ever-expanding range of aspects of modern life through contracting regimes directed at the attainment of particular policy purposes. In Britain, this mode of governance has been problematic in that many contracting regimes have failed to respond adequately to public needs. While the trend toward privatization may be politically irreversible, the role of the state should be to help establish the conditions that enable all parties with stakes or interests in particular public services to participate in collective learning processes aimed at addressing deficiencies in existing provisions.
\end{abstract}

\section{INTRODUCTION}

Public services in advanced economies are increasingly provided through a hybrid combination of mechanisms of public and private ordering. The general expansion in the role of the private sector has not been accompanied by a corresponding "retreat" of the state, nor has there occurred any simple shift in the mode of governance from public to private. ${ }^{1}$ Again, most modern privatization initiatives fall

- Professor of Law, University of Leeds.

1. Peer Zumbansen, The Governance of Contracting: The Province of Administrative Law in an Era of Contractualized Government, in Non-Profit Yearbook 2002 61, 83-84 (W.Rainer Walz, Hein Kötz, Karsten Schmidt et al. eds., 2003). The notion of retreat is better suited to the analysis of changing patterns of governance in specific sectors, for example the "vanishing trial" in the field of civil justice, and the shift in the governance of the world economy away from nation states toward a range of non-state authorities, big firms, and international bureaucracies. See Susan Strange, The Retreat of the State: The Diffusion of Power in the World Economy 4 (1996). 
far short of the wholesale transfer of responsibilities from the public sector into the domain of the market. The sharing of responsibilities among networks of public and non-state actors is variously reflected in notions of the third sector, ${ }^{2}$ mixed administration, ${ }^{3}$ and third-party government. ${ }^{4}$ Leaving to one side for present purposes legal and doctrinal debates, ${ }^{5}$ this article explores the hybrid character of contemporary public service organization with specific reference to the emergence in Britain over the last twenty-five years of a novel mode of governance, which I term the New Public Contracting. ${ }^{6}$

The first section defines the nature and scope of this phenomenon and traces its genealogy. The second section provides a brief overview of the major problems of ineffectiveness and lack of legitimacy associated with this form of regulation and specifies some prerequisites for increased responsiveness. In the concluding section, I argue that a major task of responsive law is to guarantee the conditions of legitimate decision-making about how public services are provided, and about the policy purposes underlying regulatory interventions. I also suggest that the role of the state should be to establish conditions that enable all parties (including citizens and consumers) with stakes or interests in particular public services to participate in and contribute to collective learning processes aimed at addressing deficiencies in existing provisions.

2. Mark Freedland, Law, Public Services, and Citizenship - New Domains, New Regimes?, in Public Services and Citizenship in European Law: Public and Labour Law Perspectives 1, 2 (Mark Freedland and Silvana Sciarra eds., 1998) [hereinafter Public Services]. The continued regulatory role of the State in respect to privatized functions is explained in terms of the partial or incomplete nature of transfers to the private sector, "leaving the activity in question perched between the public and private sectors in a genuinely distinctive situation, which should be regarded as constituting a third sector." Id. at 4.

3. Mark Aronson, A Public Lawyer's Responses to Privatisation and Outsourcing, in The Province of Administrative Law 40, 52-53 (Michael Taggart ed., 1997).

4. Lester M. Salamon, The Tools Approach and the New Governance: Conclusion and Implications, in The Tools Of Government 600, 604 (Lester M. Salamon ed., 2002).

5. See, e.g., A.C.L. Davies, Accountability: A Public Law Analysis of Government by Contract ix-xi (2001); Ian Harden, The Contracting State 50-51 (Norman Lewis \& Cosmo Graham eds., 1992); Peter Vincentr-Jones, The New Public Contracting: Regulation, Responsiveness, Relationality 275-310 (2006); Alfred C. Aman, Administrative Law for a New Century, in The Province of Administrative Law, supra note 3, at 90, 116; Jody Freeman, Collaborative Governance in the Administrative State, 45 U.C.L.A. L. Rev. 1, 3-4 (1997); Salamon, supra note 4 , at $600-10$.

6. See Vincent-Jones, supra note 5. 


\section{Policy-driven Regulation}

The New Public Contracting reflects concerted efforts by both Conservative and Labour administrations since the 1980s to govern an ever-expanding range of aspects of modern life through contracting regimes directed at the attainment of particular policy purposes. ${ }^{7}$ Within such regimes: (1) administrative contracts regulate relationships between parts of government; ${ }^{8}$ (2) economic contracts promote outsourcing in central and local government ${ }^{9}$ and serve in the quasi-market restructuring of entire welfare sectors and the procurement of public infrastructure such as schools and hospitals; $;{ }^{10}$ and (3) social control contracts operate as instruments of behavioral modification in the regulation of relationships between state agencies and deviant or "problem" citizens." The common regulatory feature is the delegation of powers and responsibilities to public agencies in a variety of contractual arrangements preserving central government controls and powers of intervention. However, there exists an important difference. While administrative contracts may be considered a form of hierarchical regulation, both economic contracts and social control contracts are the product of more complex contracting regimes involving regulation by contract within hierarchical regulatory frameworks. Economic contracts and social control contracts are illustrative of government at a distance, ${ }^{12}$ combining central steering through the conditions set hierarchically within the contracting regime on the one hand with an element of lower-level coordination through the

7. Id.at 124-136. A "contracting regime" is a regulatory regime in which the mechanism of contract plays a principal role. A regulatory regime may be defined as "a historically specific configuration of policies and institutions which structures the relationship between social interests, the state, and economic actors in multiple sectors of the economy." Marc Allen Eisner, RegulaTory Politics in Transition 1 (1993). The term is understood here to refer to the structuring of relations more broadly, within government and in the maintenance of social control as well as in economic organization. See Jody Freeman, Private Parties, Public Functions and the New Administrative Law, 52 Admin. L. Rev. 813, 857 (2000).

8. This usage should not be confused with that in civil law jurisdictions, where the term "administrative contract" typically refers to concession contracts, or contracts for the provision of public services or public utilities, in which at least one of the parties is a state or administrative agency. In the present categorization these are economic contracts. See Vincent-Jones, supra note 5, at 141-43.

9. Id. at 198.

10. Id. at 211-12.

11. Id. at 230 .

12. Miller and Rose stress the importance of indirect mechanisms of government that link the conduct of individuals and organizations to political objectives through "action at a distance." Peter Miller \& Nikolas Rose, Governing Economic Life, 19 Econ. \& Soc'y 1, 1 (1990). 
(strictly limited and contingent) devolution of contractual powers to designated public agencies on the other hand. The "public" regulatory dimension consists of the state's harnessing of contract as an instrument of governance, in stark contrast with the more familiar role of the law of contract as a mechanism of self-regulation of business or other private relations. ${ }^{13}$

The function performed by economic contracts is different not only to traditional public procurement in which one of the parties is the government or a public body contracting with the private sector, but also to the pursuit of policy goals through contractual terms that are secondary or ancillary to the main public procurement purpose. ${ }^{14}$ The claim of "newness" in this context rests on the analytical distinction between such general regulation through the medium of contract, and what Mark Freedland has described in relation to the Private Finance Initiative (PFI) as "positive policy-driven regulation."15 The latter represents a novel type of government by contract, or governance through contract, aimed at achieving quite specific policy objectives. Since Labour came into power in 1997, such instrumental use of contract has spread rapidly beyond the sphere of economics into public administration and social policy. Policy continuity has been a feature of contractualization in the public sphere in Britain over the past 25 years. ${ }^{16}$

\section{A. Genealogy}

The economic form of the New Public Contracting may be traced to the introduction, by the Conservatives, of Compulsory Competitive Tendering (CCT) in local government through primary legislation in 1980. Similar pressures encouraging contracting out services at the expense of direct provision were applied through market testing initially in the National Health Service (NHS) from 1983 and later in central government from 1991. The use of private finance to fund public infrastructure projects through the PFI began in 1993. These reforms were accompanied by the creation and continuous modification of quasi-markets - in housing and education from the beginning of the 1980 s and in health and social care under the

13. See Hugh Collins, Regulating Contracts 13 (1999).

14. See Terence Daintith, Regulation by Contract: The New Prerogative, 32 Current Legal. Probs. 41,41 (1979).

15. Mark Freedland, Government by Contract and Public Law, Pub. L., Spring 1994, at 86, 87.

16. "Contractualization" here refers to the process of transition from direct hierarchical state provision towards a more decentralized mode of governance that nevertheless maintains a role for central government in standard-setting, monitoring, and enforcement. See Vincent-Jones, supra note 5 , at $311-20$. 
National Health Service and Community Care Act 1990. Far from implying withdrawal of the state, quasi-market organization entails an intensification of governmental activities directed at building markets, allocating responsibilities among the public and private agencies engaged in public service networks, and establishing other regulatory conditions for more effective or efficient service provision. ${ }^{17}$ After the 1997 general election, New Labour's program for "Modernising Government" was pursued through revised guidance in the form of Better Quality Services. This guidance applied to a wide range of public contracting functions of central government, including market testing, outsourcing, and public-private partnerships. In a parallel initiative, the Local Government Act 1999 imposed on public authorities the "best value" dury to secure continuous improvements in their performance with regard to economy, efficiency, and effectiveness. These regimes - the successors to policies of market testing and CCT-have continued to facilitate the contracting out of services formerly provided directly. Similarly, the PFI was enthusiastically adopted and developed by Labour in the late 1990s, becoming the principal vehicle for the funding of new schools, hospitals, prisons, and other public infrastructure projects. Since the 2001 general election, the health and education sectors have been subjected to further quasi-market reforms under the Health and Social Care Act 2001 (granting Strategic Health Authorities new powers in respect of Public Private Partnerships); the Health and Social Care Act 2003 (creating NHS Foundation Trusts with the legal capacity to enter enforceable contracts with NHS Primary Care Trusts); the Education Act 2002 (governing the creation of Academies as corporate entities); and the Higher Education Act 2004 (introducing variable tuition fees aimed at increasing competition and student choice in tertiary education).

The restructuring of relations within government on the basis of administrative contracts began in the late 1980s. From this time government departments were required to review all their functions with a view to abolition, privatization, contracting out, or creating a Next Steps agency. In the latter case, the relationship between the executive agency and its parent department was governed by a framework document or agreement. Such guidance has continued in revised form under New Labour. In addition, relationships between the Treasury and spending departments were cast as Public Service Agreements (PSAs) as part of the first Comprehensive Spending Review in 1998 and repeated in 2000, 2002, and 2004. This development has been driven by a managerial reform agenda con-

17. See Alberta M. Sbragia, Governance, the State, and the Market: What Is Going On?, 13 GoverNANCE $243,246(2000)$. 
cerned, like Next Steps, with restructuring administration and increasing efficiency in the operation of government. ${ }^{18}$

Finally, the use of contract as a statutorily imposed mechanism of behavioral modification began in the field of social security with the Jobseekers Act 1995, which made the payment of state benefits conditional upon specific contractual undertakings entered into by welfare recipients. Under New Labour, the School Standards and Framework Act 1998 and the Youth Justice and Criminal Evidence Act 1999 introduced home-school agreements and youth offender contracts respectively. Parenting contracts were then introduced under the Anti-Social Behaviour Act 2003. Drawing on "new contractualist" discourse, ${ }^{19}$ reform in all these instances has been directed at improving standards of behavior among deviant individuals or groups regarded as socially problematic, including youth offenders, school children, and parents.

The remainder of this article will focus on economic contracting regimes. One objective of policies introducing competitive procedures is to reduce costs and to improve the quality of public services. The market, it is presumed, is more likely to be able to achieve both productive and allocative efficiency than state provision. However, just as important as the attainment of value for money, and distinct from it, have been the policy goals of transferring public service functions out of the state sector, reducing the size of public bureaucracies, increasing the role of private and voluntary providers, and curbing the powers of the public sector unions. ${ }^{20}$ The substantive thrust of central government policy since the 1980s has been about the transition from bureaucratic to non-state provision through exposure to competitive processes.

18. VinCENT-Jones, supra note 5, at 142.

19. Anna Yeatman, Interpreting Contemporary Contractualism, in Governing Australia: Studies in Contemporary Rationalities of Government 228 (Mitchell Dean \& Barry Hindess eds., 1998).

20. Vincent-Jones, supra note 5, at 120; see also Brian Abbott, Robert A. Blackburn \& James Curran, Local Authority Privatisation and Markets for Small Businesses, Loc. Gov'т Stud., Autumn 1996, at 72, 72. See generally Carol. Harlow \& Richard Rawlings, Law and Administration 252 (1984); Dawn Oliver, Government in the United Kingdom: The Search for Accountability, Effectiveness and Citizenship 80-82 (1991) (discussing the growing trend in the United Kingdom of transferring functions from the local government to other bodies); Mike Radford, Competition Rules: The Local Government Act 1988, 51 Mod. L. Rev. 747, 748 (1988) (Eng.) (discussing how consideration of the cost and advantages of contracting services out to the private sector was a part of the legislative history of the $1988 \mathrm{Act}$ ). 


\section{B. Centralized Decentralization ${ }^{21}$}

The relationships comprising economic contracting regimes may be modeled along five separate axes (Fig 1): (a) purchaser-provider; (b) state-purchaser; (c) state-provider; (d) citizen/user-purchaser; and (e) user-provider. By comparison with hierarchical organization, such regimes entail a significant degree of devolution and decentralization. The purchaser-provider relationship and the contracting process are relatively independent of direct government control. Public purchasing agencies (such as local councils and health and education authorities) exercise a range of discretionary contractual powers, monitoring and evaluating the performance of service providers in the private or nonprofit sectors in accordance with contract terms, specifications, and standards. In many cases their discretion extends to the prior decision whether a service should be outsourced (rather than remain in-house) or provided under some other arrangement such as a public-private partnership.

Figure 1: Economic Contracting Regime

STATE

Central government department
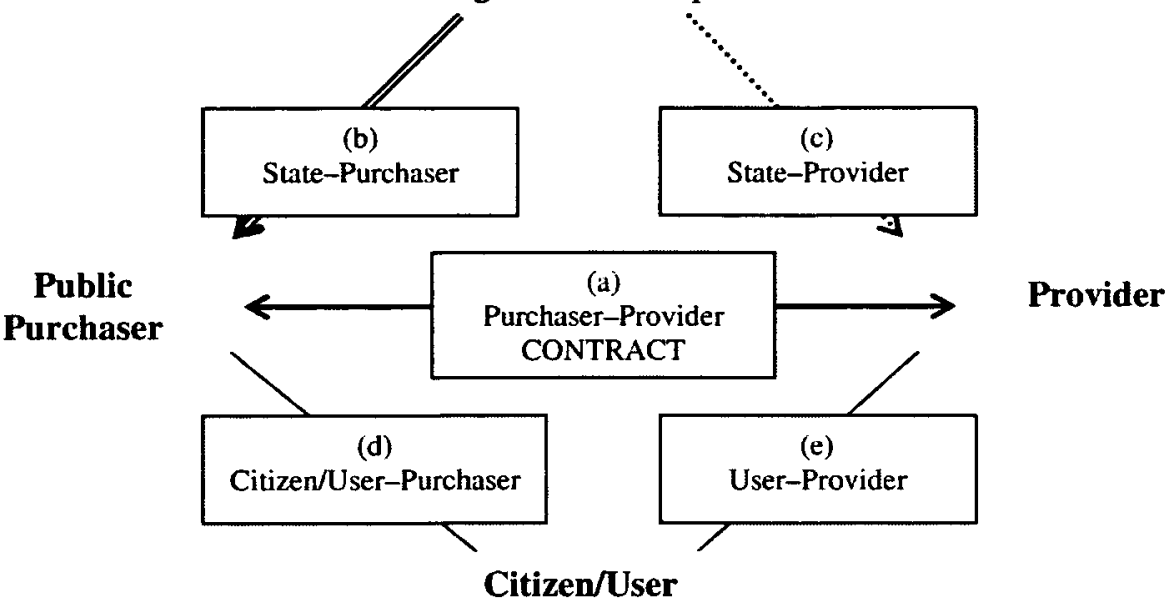

21. Ian Kirkpatrick \& Miguel Martínez Lucio, Introduction: The Contract State and the Future of Public Management, Puв. Admin., Spring 1996, at 1, 5. 
However, the essence of the New Public Contracting is that such decentralization is accompanied by increasing centralization. The apparent paradox of devolution combined with increased bureaucratic control over strategy and policy is part of a wider shift in modes of control in the public service. ${ }^{22}$ "The approach is one of centralization and decentralization at the same time; centralization of policy and the setting of the parameters within which the system works, and decentralization of operational management." ${ }^{23}$ Hence contract and market forces combine with, rather than substitute for, hierarchy and bureaucracy. ${ }^{24}$ While the devolution of powers creates the possibility of increased choice and discretion on the part of public service managers, the promise of autonomy is undercut by the conditions imposed by the constitutive regimes and their sanctioning capacities. ${ }^{25}$ New Public Contracting policies reflect the continuing trend, in England at least, ${ }^{26}$ toward centralization of power and increasing government control over the activities of subunits of central government, local councils, and public and professional bodies in the fields of law, education, health, and social services. While centralization is a familiar theme in the analysis of the relationship between central and local government, ${ }^{27}$ it is manifested also in the restructuring of relations within government and in other public service settings. Indeed, the commitment to national frameworks of standards and accountability in all public service fields was an explicit part of the second phase of New Labour's Modernising

22. Paul Hoggett, New Modes of Control in the Public Service, Pub. Admin., Spring 1996, at 9, 9.

23. Nicholas Deakin \& Kieron Walsh, The Enabling State: The Role of Markets and Contracts, Pub. Admin., Spring 1996, at 33, 36-37.

24. K. Shaw, J. Fenwick, and A. Foreman, Compulsory Competition for Local Government Services in the UK: A Case of Market Rhetoric and Camouflaged Centralism, 10 Puв. PoL'y \& Admin. 63 (1995).

25. See John Benington, The Modernization and Improvement of Government and Public Services, Pub. Money \& Mgmt. (Special Issue), Apr.-June 2000, at 3, 6; Stephen Cope \& Jo Goodship, The Audit Commission and Public Services: Delivering for Whom?, Pub. Money \& Mgmt., Oct.-Dec. 2002, at 33, 35 .

26. Devolution in the United Kingdom has resulted in significant policy divergence on a range of public service issues. While competition and market reforms are being embraced with enthusiasm in England, reform in Scotland and Wales is occurring within more traditional bureaucratic organization. See M. Sullivan and M. Drakeford, Devolution, Divergence and Social Policy, 3 WALES J.L. \& PoL'y 7 (2005).

27. Martin Loughlin, The Restructuring of Central-Local Government Relations, in The Changing Constitution 261, 261-62 (Jeffrey Jowell \& Dawn Oliver eds., 3d ed. 1994); see Ian Leigh, Law, Politics, and Local Democracy (2000); Martin Loughlin, Legality and Locality: The Role of Law in Central-Local Government Relations 60-61 (1996); Martin Loughlin, Understanding Central-Local Government Relations, Pub. Pol'y \& Admin (Special Issue), Summer 1996 , at 48,48 . 
Government agenda. ${ }^{28}$ Under the Education Act 2002 and Health and Social Care Act 2003, education and health authorities that are considered to be failing in their public service duties are liable to various central enforcement measures and powers of intervention. ${ }^{29}$

A major plank in the government's program for public service reform has been the commitment to increasing supply-side competition and consumer choice-whether exercised directly by service recipients or indirectly on their behalf by representative public agencies. Where public providers remain under government control, as in health and education, they are being encouraged to become more entrepreneurial through increased management freedoms granted in "foundation" or other forms of corporate status. At the same time, public purchasing agencies such as Primary Care Trusts are being given greater autonomy and wider powers to commission treatment from the cheapest sources in the public, private, and nonprofit sectors. Contracting out and outsourcing in central and local government remain just as much the product of positive policy-driven regulation as in the days of more overtly compulsive regimes of CCT and market testing. As with the PFI, the normative structures governing these forms of public contracting include not just a set of identifiable and separable rules of operation, but "a set of ideas or guiding principles which emerge from a large body of partly presentational and explanatory material. ${ }^{30}$

\section{Responsiveness: Economic Contracts and Public Services}

The experience of the New Public Contracting in Britain has proved highly problematic. While arguably there exists potential for contracts to serve responsively in the performance of a range of public service functions, in many cases contracting regimes have demonstrably failed or are at risk of failure. Responsiveness deficits here are due to a combination of problems of regulatory ineffectiveness and lack of legitimacy. ${ }^{31}$ The principal legitimacy deficit consists in the lack

28. Cabinet Office, Effective Performance Division, The Second Phase of Public Sector Reform: The Move to Delivery (Mar. 22, 2002), http://archive.cabinetoffice.gov.uk/eeg/secondphase.htm.

29. Health and Social Care (Community Health Standards) Act 2003, c. $43 \S 23$, available at http://www.opsi.gov.uk/ACTS/acts2003/30043--b.htm\#23 (last visited March 2, 2007); Education Act 2002, c. $32 \S 54$, available at http://www.opsi.gov.uk/ACTS/acts2002/ukpga_20020032_ en_7\#pt4-pb1-1lg54 (last visited Nov. 5, 2007).

30. Freedland, supra note 15 , at 89.

31. While effectiveness denotes the efficient deployment of means to the attainment of given ends, legitimacy refers to the need both for public deliberation in the determination of fundamen- 
of adequate opportunity for citizen involvement and for public deliberation in policy and decision making. While there might be good arguments in favor of contractualization, these remain opaque and difficult to evaluate given the absence under the U.K. Constitution of adequate procedures that promote accountability and transparency. ${ }^{32}$

Such legitimacy deficits are intimately linked with regulatory ineffectiveness. The fundamentally dyadic character of regulatory linkages in economic contracting regimes poses an immediate obstacle to collective learning, ${ }^{33}$ in particular as regards the exclusion from regulatory processes (for example, standard-setting, monitoring, and enforcement) of consumers and citizens whose contribution as major stakeholders is vital to the resolution of public service problems. ${ }^{34} \mathrm{~A}$ further source of regulatory ineffectiveness concerns "implementability," or the difficulty of operating policy programs:

The more complex and convoluted the tool, the more separate actors are involved, the more difficult it is likely to be to manage. Some tools are more cumbersome to operate than others. While they may promise great efficiency and effectiveness in theory, they

tal policy goals, and for the nurturing of qualities of institutional morality and values of good administration within organizations engaged in public service networks. VINCENT-Jones, supra note 5, at 87, 104; see Peter Vincent-Jones, Values and Purpose in Government: Central-local Relations in Regulatory Perspective, 29 J.L. \& Soc'y 27, 49, 53 (2002).

32. See generally VinceNT-Jones, supra note 5, at 311-45 (discussing contractualization in contemporary Britain and arguing that the disclosure of information is necessary to promote transparency and foster public deliberation).

33. See J. Lenoble \& M. Maesschalck, Beyond Neo-Institutionalist and Pragmatist Approaches to Governance (Reflexive Governance in the Pub. Interest, Working Paper No. REFGOV-SGI/ TNU-1, 2006, available at http://refgov.cpdr.ucl.ac.be/?go=publications (last visited July 9, 2007) (discussing the importance of building capacities for collective learning among stakeholders in public services). For a general discussion of social learning, see Charles F. Sabel, Learning by Monitoring; The Institutions of Economic Development, in The Handboox of Economic Sociology 137 (Neil J.Smelser \& Richard Swedberg eds., 1994). For the application of social learning in the public service context, see Charles F. Sabel, Globalisation, New Public Services, Local Democracy: What's the Connection?, in Local Governance and the Drivers of Growth 111 (2005), available at http://213.253.134.29/oecd/pdfs/browseit/8405041E.PDF; C. F. Sabel, Beyond Principal-Agent Governance: Experimentalist Organizations, Learning, and Accountability, in De StaAT VAN DE Democratie: Democratie Voorbij De Stant 173 (Ewald Engelen and Monika Sie Dhian Ho eds., 2004).

34. See generally Peter Vincent-Jones, Citizen Redress in Public Contracting for Human Services, 68 Mod. L. Rev. 887 (2005) (Eng.) (discussing public contracting for human services from a regulatory perspective). 
are unlikely to deliver it in practice because of the managerial difficulties they pose. ${ }^{35}$

These epithets ("cumbersome," "complex," and "convoluted") aptly describe the problems of regulatory coordination posed by economic contracting regimes. The effectiveness of economic contracts as regulatory instruments is ultimately dependent on the quality of relationships both vertically between central government and the public agency to whom contractual powers have been devolved and horizontally between the public agency and the service provider. In other terminology, economic contracting regimes involve a problematic combination of "directness" and "automaticity," where directness refers to "the extent to which the entity authorizing, financing, or inaugurating a public activity is involved in carrying it out," and automaticity "measures the extent to which a tool utilizes an existing administrative structure to produce its effect rather than having to create its own special administrative apparatus. ${ }^{37}$ While in business and other private relations contract serves as a mechanism of joint utility maximization through which the parties may govern and adjust their ongoing relationships to mutual benefit, ${ }^{38}$ such welfare-enhancing conditions are much more problematic and difficult to attain through programs of policy-driven regulation involving public contracting. The top-down nature of contracting regimes has a tendency to damage the norms that support trust and cooperation in these contractual relations, thereby impeding the overall attainment of the government's policy objectives. Furthermore, public authorities are under pressure to adopt forms of organization that may not be suited to the circumstances, or to the needs or preferences of citizens and consumers. ${ }^{39}$

Various conditions would need to be satisfied in order for contract to serve responsively as an instrument of public service regulation. ${ }^{40}$ Four such prerequisites

35. Lester M. Salamon, The New Governance and the Tools of Public Action: An Introduction, in The Tools of Government, supra note 4, at 24.

36. Id. at 29. Note that, "[a] direct tool is one in which authorization, funding, and execution are all carried out by essentially the same entity." Id.

37. Id. at 32 . The greater the reliance on market forces, the more automatic are governance tools in their implementation.

38. See David Campbell \& Donald Harris, Flexibility in Long-term Contractual Relationships: The Role of Co-operation, 20 J.L. \& Soc'y 166, 167 (1993).

39. The recent experience of contractual difficulties in fields as diverse as the procurement of schools and hospitals under the PFI and the contracting out of residential and nursing care services for vulnerable citizens begs the question whether these public service functions might be performed more effectively by the state directly.

40. See Vincent-Jones, supra note 5, at 348-49. 
may be described as relational, and are concerned mainly with the appropriate support in governance relationships of the contract norms. These relational elements are necessary, but not sufficient, conditions of responsive contractual regulation. Stable and cooperative relationships that benefit regulators and regulatees might be a mask for inefficiency, ineffectiveness, or fraud and corruption. ${ }^{41}$ The result in such a case would be to defeat the overall purpose of the regulatory regime. Again, the efficiency gains of relational contracting might be outweighed by disproportionate damage to other values such as equity or social justice, or harm to the interests of other stakeholders, such as consumers. Accordingly, a further set of conditions must be specified, referring to institutional and organizational aspects of the design of contracting regimes.

\section{A. Relational Conditions}

The first relational condition is sensitivity on the part of regulators to the circumstances in which regulation occurs, implying the existence of some degree of cooperation between regulators and regulatees. In the economic context, this quality is necessary both in the hierarchical regulatory relationship between central government and public agencies, and in the contractual relationship between such agencies and the other contracting party. ${ }^{42}$ Lack of regulatory sensitivity on the part of central government may be expected to have a negative impact on the capacity of public agencies to perform their contractual regulatory roles effectively. ${ }^{43}$ Economic contracting regimes under the Conservatives in the era of CCT and compulsory market-testing were highly adversarial and marked by regulatory insensitivity. The generally less confrontational style adopted by New Labour since 1997 has not altered the underlying tensions in relationships between central government and local councils, health authorities, NHS Trusts, and other regulated entities performing public service functions. Regulatory sensitivity implies not only the general avoid-

41. Willie Seal \& Peter Vincent-Jones, Accounting and Trust in the Enabling of Long-Term Relations, 10 Acct. Auditing \& Accountability J. 406, 410 (1997).

42. The overlap with the specifically contractual norms that support trust and cooperation in the performance of contracts is considered under the fourth point.

43. This dimension has been least problematic in the case of administrative contracts, where the bureaucratic and contractual elements in contracting regimes are combined in a relatively simple regulatory structure, and the relationships are solely between levels of government. See VincentJoNEs, supra note 5 , at 25-29. 
ance of adversarial relations and the minimum use of legitimate force, ${ }^{44}$ but also the existence of active collaboration and partnership in regulatory relationships. This applies to the design and modification of contracting regimes as well as their practical operation. Contracting regimes need to be designed and managed from the 'bottom-up,' with greater involvement of professional groups and other stakeholders from the outset, rather than imposed from the 'top-down' in pursuit of the government's predetermined policy agendas.

Second, contractual relationships are defined essentially by the presence of norms of planning and consent, which are necessary to support discreteness and presentiation and to enable the parties to structure their relations productively. ${ }^{45}$ These norms are usually relatively unproblematic in economic contracts. ${ }^{46}$ Where the threshold conditions of contractual relations have been established, responsiveness is further dependent on the embedding of contractual institutions to an appropriate depth within public service relationships.

The third condition, accordingly, refers to the need to balance discrete norms with relational norms promoting fairness and reciprocity. The failure or weakness of the latter may be a source of problems for the public agency, for the other contracting party, or for both parties. ${ }^{47}$ Overall, institutional strengthening may be nec-

44. It should be emphasized that the quality of regulatory sensitivity does not rule out force and compulsion, rather implies limits on the use of such measures to circumstances where they are necessary to achieve legitimate policy and regulatory goals. See Vincent-Jones, supra note 31, at 27 (discussing the relationship between central and local government from theoretical perspectives).

45. See Ian R. Macneil, The New Social Contract: An Inquiry into Modern Contractual ReLATions 60 (1980) ("Discreteness is the separating of a transaction from all else between the participants at the same time and before and after. ... Presentiation, on the other hand, is the bringing of the future into the present. Underlying both is the ideal of 100 percent planning of the future.").

46. In administrative contracts and social control contracts, by contrast, a major source of regulatory ineffectiveness in some instances has been the failure to secure the threshold conditions of discreteness and presentation that are the essence of functioning contractual relations. The norms of planning and consent are essential to any contract. Where these elements are absent, nothing of value is exchanged and there can be no possibility of welfare being jointly maximized by contractual means.

47. There are particular problems in this regard with framework documents linking government departments and executive agencies and Youth Offender Contracts and Parenting Contracts. Peter Vincent-Jones, Contractual Governance: Institutional and Organizational Analysis, 20 Ox ForD J. Legal Stud. 317, 345-48 (2000). 
essary to improve regulatory effectiveness, ${ }^{48}$ and/or to provide safeguards against unfairness to the party in the weaker bargaining position. ${ }^{49}$

Fourth, there must be trust and cooperation in the performance of contracts. If the norms supporting trust and cooperation become damaged or otherwise cease to function properly, it cannot be expected that obligations will be fulfilled, or that the potential welfare benefits of contract will be realized. The analytical focus is on the success or failure of the state's regulatory efforts to secure conditions of contracting in which each party can trust with confidence in the cooperation of the other. ${ }^{50}$ Severe damage to a number or all of the contract norms may result in the failure of a particular contract, and/or the total breakdown or unworkability of the contracting regime. The empirical socio-legal literature is replete with examples of transaction difficulties and costs associated with the undermining of trust and cooperation in economic contracts. ${ }^{51}$ The catastrophic failure of some PFI projects mirrors the problems that were encountered during the 1990 s with the more overtly compulsory policy-driven programs of CCT and market-testing. Even where the damage to contract norms is less severe, and is expressed in less serious tensions in the management and operation of the contracts, the long-term consequences for the relationship may be disastrous. Contracting regimes should be designed and managed in a way that not only avoids undermining the norms that support trust and cooperation, but also actively promotes those relational qualities.

\section{B. Institutional and Organizational Conditions}

Turning to the institutional and organizational dimensions, the fifth condition of responsiveness concerns the ability of the system of governance to facilitate collective learning and institutional morality among the various public, private, and voluntary bodies engaged in public service networks. On the one hand, both regulating

48. Bindingness is not generally a problem for the party using the contract as an instrument of regulation. What remains problematic in contracts that are not legally enforceable, however, is the lack of reciprocity in the sense of the relative inability of the regulatee effectively to enforce the obligations undertaken by the state agency.

49. For a general discussion of a range of solutions in mainstream legal debates designed to counter the problem of unfairness in some purchaser-provider relationships, see VinCENT-Jones, supra note 5, 167-99.

50. Campbell \& Harris, supra note 38, at 184.

51. See generally Peter Vincent-Jones, D. Campbell, A. Harries, \& W. Seal, Econ. \& Soc. Res. Couns. , Conflict and Cooperation in Contracting for Professional Services: A ComparaTive Study (1998). 
and regulated entities need to adapt within and learn from their environments, taking account of new information and adjusting their activities to core values and purposes. ${ }^{52}$ This can occur effectively only if all parties in the network, including citizens and consumers, have the requisite capacities and are able to contribute to collective learning in a continuous process of evaluation and revision. ${ }^{53}$ On the other hand, non-state bodies acquire ethical and moral responsibilities in respect of service provision by virtue of their performance of specifically public functions. ${ }^{54}$ Responsiveness requires the inculcation within particular service sectors and industries of values of good administration, fairness, and nondiscrimination through self-regulation backed ultimately by legal sanctions..$^{55}$ Institutional morality is also a prerequisite of the responsive operation of public agencies engaged in policy development and decision making at the heart of government.

Sixth, there should exist effective mechanisms for the redress of grievances, coupled with the securing of citizen empowerment through appropriate fora of public participation. The concept of hybrid regulation may provide a key to developing effective complaint mechanisms and forms of redress of grievances, combining formal law and legal procedures with more informal institutional processes that operate within all organizations engaged in public service networks. ${ }^{56}$ The commitment to restorative justice as a component of responsiveness requires that remedial hierarchies should serve to effect reparation to the citizens who have legitimate grievances in respect of the organization and provision of public ser-

52. See Vincent-Jones, supra note 31. Elsewhere, I suggest (i) that further research should investigate the link between collective learning by bodies performing public service functions, and relationality as a quality of regulatory relationships in public service networks; and (ii) that this research should test the hypothesis that the latter is a necessary condition of the former. VincentJoNEs, supra note 5, at 353 . By this I meant that where the mode of economic organization is contractual, the capacity for collective learning among the parties involved in the contracting regime is likely to be dependent on the quality of relationality in the constituent regulatory relationships. I did not mean to imply that collective learning cannot occur through other (non-contractual) processes. The role of collective learning in reflexive governance is the subject of the Sixth European Framework Program in Research and Development's integrated project, "Reflexive Governance in the Public Interest." For more information on this project, see Reflexive Governance in the Public Interest, http://refgov.cpdr.ucl.ac.be (last visited Apr. 4, 2007).

53. See Ian Sanderson, Evaluation, Policy Learning and Evidence-Based Policy Making, 80 Pub. Admin. 1,19 (2002).

54. For a general discussion on the identity, loyalty and responsibilities of employees in network forms of organization, in the context of the blurring of the public-private divide, see Jill Rubery, Jill Earnshaw, Mick Marchington, Fang Lee Cooke \& Steven Vincent, Changing Organizational Forms and the Employment Relationship, 39 J. Mgмт. Srud. 645 (2002).

55. See Vincent-Jones, supra note 34 at 918-919.

56. Id. 
vices. ${ }^{57}$ Citizen empowerment is dependent on the development of new voice mechanisms to counter the imbalance created by the emphasis in recent government policy on choice and exit. ${ }^{58}$ The existence of such mechanisms is also likely to be a precondition of effective collective learning. The decision whether a service should be outsourced, provided directly, or provided under some other arrangement should be subject to notice and comment and other publicity and consultation requirements. Standard-setting procedures in particular service sectors should be designed to involve both consumers and provider organizations. Specific representative institutions may be needed to enhance the legitimacy and responsiveness of decisions on rationing services and to overcome the impasse presented by judicial reluctance to interfere with the merits of such decisions. The role of representative bodies need not be confined to the implementation of existing policy, but should extend to deliberation over fundamental issues of policy direction, for example, concerning contracting out, privatization, Academies, and the PFI. ${ }^{59}$ What is important is that the agendas for debate in such deliberative fora are locally and democratically determined rather than imposed from above by central government in support of preconceived programs of public service reform..$^{60}$

Seventh, public agencies to whom responsibilities have been devolved in contracting regimes require appropriate legal powers and resources to perform their public service functions. Responsiveness in various senses might be increased through relaxation of current rules that disallow noncommercial considerations in the tendering and the award of contracts. The principle of subsidiarity requires that a wider margin of appreciation be permitted to local councils and other public agencies in making their own value and policy choices and in deciding whether and how contract should be used as an instrument of regulation in their pursuit. The regulatory capacity of public agencies is also dependent on an appropriate

57. See generally John Braithwaite, Restorative Justice \& Responsive Regulation (2002) (arguing that restorative justice is about restoring victims, offenders and communitites through the participation of a variety of entities).

58. See generally Vincent-Jones, supra note 5, at 210-15 (discussing the concepts of "voice" and "exit and choice" and how responsiveness depends on a balance between the two).

59. Cf. Neal Ryan, Reconstructing Citizens as Consumers: Implications for New Modes of Governance, Austl. J. Pub. Admin., Sept. 2001, at 104 (discussing the negative impact that results from treating citizens as consumers and the emergence of ideas of public-private partnerships to replace old consumer models).

60. For a general discussion on the inherent limitations of government public participation initiatives in major service sectors such as health, see Rosemary Rowe \& Michael Shepherd, Public Participation in the New NHS: No Closer to Citizen Control?, 36 Soc. Pol'y \& Admin. 275 (2002). 
level of resources, whether provided directly by central government or raised independently. In the case of local government, the shortage of resources is linked with the restriction of legal powers to raise revenues from local taxation. Contractual capacity in both senses must be built into the design of contracting regimes if they are to have any realistic chance of achieving their legitimate public service objectives.

The final condition of responsive regulation refers to transparency, public deliberation, and public accountability in both policymaking and implementation. This condition is closely linked to that concerning citizen empowerment. A major task of responsive law is to structure the exercise of discretion by ministers and officials through a combination of procedural and informational requirements. These would govern both the making of policy at the highest levels within government, and its implementation at lower levels by public agencies or authorities in particular instances. Such a legal framework should ensure that policy objectives are made explicit, and that policy formulation, development, and evaluation are subject to proper deliberation and public scrutiny. It should also ensure that official decision making is transparent, and that bureaucratic actors are properly accountable to legitimate sources of authority for their performance of public service functions. This requires the positive commitment at all levels of public administration to principles of open government and freedom of information. The making of effective choices between different forms of public service organization, the selection of the best type of contractual arrangement and of the contracting partner, and the accountability of decision makers for their actions are all to some degree dependent on the quality and availability of information. Where it is decided that public services should be organized on a contractual basis, information about the contract process is vital for holding the government accountable and for assessing its performance. The goal of institutionalizing respect for values of openness, transparency, and accountability in decision making on public services requires the radical reform of existing administrative practices and a challenge to the prevailing culture of secrecy within public sector organizations.

\section{Conclusion: Toward Democratic Experimentalism?}

Rather than conceiving of contractual governance simply in terms of public versus private ordering, this article has analyzed economic contracting regimes as a hybrid combination of elements of public direction and private enterprise. I have suggested that the inability of New Labour to deliver a responsive hybrid alterna- 
tive to market and bureaucratic organization after 1997 does not necessarily mean that contracting regimes are incapable of delivering responsive public services. From a rational policy perspective, the future of the economic form of the New Public Contracting should depend on how far the above conditions of responsiveness can be secured through legal and institutional reform. For a variety of historical, cultural, and constitutional reasons, it would appear that many of these conditions are better satisfied in other common law jurisdictions than in contemporary Britain.

The principal regulatory role for responsive law should be to guarantee the conditions in which choices and decisions may be made in as democratic and rational a manner as possible, on an ongoing and always provisional basis, about how government is organized and public services are provided, about how these functions are regulated, and about the policy purposes and values underlying regulatory interventions. ${ }^{61}$ The emphasis on procedural legitimacy as a precondition of effective policy and decision making already suggests that some public services might be organized better on some basis other than public contracting. The form of state involvement in public services may range from full public ownership and direct provision to the statutory regulation of markets through independent regulatory agencies. ${ }^{62}$ The still more fundamental question is whether a given service should be "public" at all. ${ }^{63}$ The advantage of private services in theory is that demand decisions are made according to "automatic links" established in the market, through choice and exit mechanisms and on the basis of consumer sovereignty. However, markets tend to suffer from fundamental structural problems such as information asymmetries and various economic and social inequalities. Many services have a public dimension precisely because of market failure,

61. See generally Michael C. Dorf \& Charles F. Sabel, A Constitution of Democratic Experimentalism, 98 Colum. L. Rev. 267 (1998) (discussing democratic experimentalism, a form of government that allows individual citizens to utilize their local expertise to solve problems); John S. Dryzex, Deliberative Democracy and Beyond: Liberals, Critics, Contestations (2000) (exploring the concept of democracy under the deliberative theory, which provides that individuals subject to a collective decision should be able to deliberate before deciding); Oliver Gerstenberg \& Charles F. Sabel, Directly-Deliberative Polyarchy: An Institutional Ideal for Europe?, in Good Governance in Europe's Integrated Market 289 (Christian Joerges \& Renaud Dehousse eds., 2002).

62 . Within the definition of a public service as "an activity with respect to which the public administration fulfils a fundamental role," there is nothing to imply that the state should perform the activity directly. Elisenda Malaret Garcia, Public Service, Public Services, Public Functions, and Guarantees of the Rights of Citizens: Unchanging Needs in a Changed Context, in Public Services, supra note 2 , at $57,62-63$.

63. In the sense of implying the necessity of a role for the state beyond that of guaranteeing the basic conditions of market exchange. 
reflecting the inability of private initiative to perform the task adequately. ${ }^{64}$ The pure market model may be particularly inappropriate in the provision of core welfare services or where equity goals are paramount. Welfare-consuming differs from market-consuming in a number of respects. Many of the goods are "experience goods," which are co-produced through interaction between provider and recipient of the service and conditioned by a need to consume rather than by pleasure in their consumption. ${ }^{65}$ Devolving decision making to individual consumers in markets removes precisely that element of public control and direction that is the hallmark of quasi-market organization, and which may be necessary to achieve fundamental social policy objectives such as protecting vulnerable citizens, combating social exclusion, and reducing the damaging impact of widening economic and social inequalities on society more generally.

More fundamentally, the positive role of the state should be to build capacities for involvement and participation of citizens and consumers in policy and decision making on a wide range of public service issues, including the private or public status of particular services and the nature and extent of involvement of the independent sector in their funding and provision. Where individuals are disenfranchised by poverty, disability, or other forms of economic and social disadvantage, they are less likely to be able or willing to participate in democratic processes. ${ }^{66}$ The state should accept the responsibility for establishing the conditions enabling parties with stakes or interests in public services to participate in and contribute to collective learning processes addressing deficiencies in existing modes of service organization.$^{67}$ Assuming these conditions can be established, policy-making and evaluation should then be seen as experiments in practical reason based on the pursuit of legitimate policy purposes rather than as technical exercises. Policy

64. "The origin of every public service lies in an essential or collective need which is recognized by the community at large as being impossible for private initiative to fulfill adequately." Garcia, supra note 62 , at 81 .

65. Kieron Walsh, Nicolas Deakin, Paula Smith, Peter Spurgeon \& Neil Thomas, Contracting for Change: Contracts in Health, Social Care, and Other local Government Services 30 (1997).

66. Effective citizen participation in decision making on public services requires the rebalancing of current inequalities of power in this regard. See Sherry R. Arnstein, A Ladder of Citizen Participation, 35 J. Am. Inst. Planners 216, 216 (1969).

67. For the argument that the "democratic experimentalist" approach to collective learning represents a further advance on the proceduralist reforms entailed in the "collaborative or relational" approach, see Lenoble \& Maesschalck, supra note 33, at 80-105 (contending that the final stage in the analytical trajectory of the development of reflexive governance is the "internal and pragmatic" approach to collective learning). 
conjectures should be subject to continuous testing, review, and evaluation, to assess whether they have worked, and if so to understand how and why. ${ }^{68}$ The experience of other countries or systems should serve not as a template, but to prompt critical introspection and policy learning. A responsive policy process should aim to maximize deliberation and scrutiny of arguments and claims made by advocates of particular positions, exposing ambiguities or ambivalence, and teasing out different layers of meaning. ${ }^{69}$

However, in the absence of a radical change in political direction or of constitutional reform controlling the pace and extent of contractualization in contemporary Britain, the drift to privatization is likely to continue. Economic contracting regimes as presently constituted appear to be a transitional stage from bureaucratic organization to ever more privatized forms of service provision. The more that consumers are brought into direct relationship with non-state providers, for example through vouchering, user fees, copayments and direct payments, the more the arrangement begins to resemble a regulated market rather than a quasimarket. Even if the responsibility for delivery of some sensitive public services is brought back under state monopoly control, the general trend may be irreversible. In the longer term, the trend may be away from regulated public contracting toward regulated private contracting in the organization and provision of public services, accompanied by an increased blurring of the boundary between regulated markets for public services and wholly private services. The state is playing a pivotal role in promoting this fundamental transition through the New Public Contracting.

68. See Sanderson, supra note 53, at 19; $c f$. Rudolf Klein, Self-inventing Institutions: Institutional Design and the U.K. Welfare State, in The Theory of Institutional Design 240 (Robert E. Goodin ed., 1996) (discussing the "experiment" brought about by the Thatcher administration's marketbased approach to the delivery of public services).

69. See VinCENT-Jones, supra note 5, at 118-20. 